\title{
Effects of Dry and Wet Seasons on Some Soil Minerals and Proteins in some Plants
}

\author{
Mona S. Al-Ahmadi \\ Department of Biology, Science College of girls, Dammam University Dammam, Saudi Arabia
}

\begin{abstract}
The Kingdom of Saudi Arabia consists of several regions with different varied climatic conditions. Eastern Saudi Arabia has a subtropical desert climate, arid basically because of its geographical situation in global patterns of atmospheric circulation. Low rainfall and high temperatures certainly class the area as a desert; five plants samples were collected in the year 2012 from different locations and different distances; they were Zygophyllum album, Halopeplis perfoliata, Cyperus conglomeratus (A) (B), Zygophyllum decumbens. Some soil minerals $\left(\mathrm{Cl}, \mathrm{Na}^{+}, \mathrm{K}^{+}, \mathrm{Ca}^{++}, \mathrm{Mg}^{++}, \mathrm{B}^{+++}\right)$and proteins concentration were investigated during dry and wet seasons. In the dry season, tested minerals concentrations increased and the difference between concentrations were significant at $p>0.05$, the protein contents decreased as a result of salt and water stress, the difference between concentrations were significant at $p>0.05$, while in the wet season, the minerals concentrations of the soil decreased, the difference between minerals concentrations were significant at $p>$ 0.05; the proteins content increased, and the difference between concentrations were significant at $p>0.05$. The littoral salt marshes show different results during dry and wet seasons, because of the character of the soil of these habitat.
\end{abstract}

Key wards: Soil minerals, Proteins, salt stress, temperature stress.

\section{Introduction}

Higher plants protect themselves from various stresses such as pathogen attack, wounding, application of chemicals including phytohormone and heavy metals, air pollutants like ozone, ultra violet rays, and harsh growing conditions, by changing their physiological conditions. These protective reactions are known as "defense responses" of higher plants, and the proteins actively synthesized in accordance with this reaction are called "defense related proteins"[1], this indicates that the great proportion of the differences was genetically determined.

Salinity, which is generally detrimental to plant growth, adversely affects the metabolism of plants and causes important modification in gene expression in plants; such modifications may lead to accumulation or deletion of certain metabolites resulting in an imbalance in the levels of a relatively small set of cellular proteins, which could increase, decrease, appear or disappear after salt treatment [2]; also salt stress induces specific protein and translatable mRNA [3., 4].

In addition, plants have evolved several mechanisms that enable them to tolerate higher temperatures. These adaptive thermo tolerant mechanisms reflect the environment in which species has evolved and they largely dictate the four major aspects of thermo tolerance that have been studied:(1) thermal dependence at the biochemical and metabolic levels; (2) thermal tolerance in relation to membrane stability; (3) induced thermo tolerance through gradual temperature increase vis-à-vis production of heat shock proteins; and (4) photosynthesis and productivity during high temperature stress [5].

In this study, five samples of plants from the flora of eastern region of Saudi Arabia were collected; the concentration of some soil minerals elements around the plants roots, and the change in proteins contents were investigated during two months of the year 2012 - Aug. (summer (dry) season) with high temperature and humidity, and Feb (winter (wet) season), with cold and low temperature, but not frozen.

\subsection{Plants collecting}

\section{Materials and Methods}

Five plants samples were collected in the year 2012 from different locations and different distances from the sea (Gulf sea); plant samples were stored in a refrigerator until testing.

\subsection{Minerals Elements analysis.}

Minerals elements concentration of soil were determined using the method described by [6] and [7].

The Sand samples were collected in plastic bags from under the surfers $(10 \mathrm{~cm}$ in depth) around the area of the roots of tested plants; samples were stored until testing. 
The $\mathrm{pH}$ value of soil first determined, and the electrical conductivity to measure the soil salinity, before analyst the soil minerals.

The soil minerals elements that had been studied were $\left(\mathrm{Cl}^{-}, \mathrm{Na}^{+}, \mathrm{K}^{+}, \mathrm{Ca}^{++}, \mathrm{Mg}^{++}, \mathrm{B}^{+++}\right)$, and the extraction methods were $\left[\mathrm{Cl}^{+}\right.$(Saturation extract), $\mathrm{Na}^{+}$(Ammonium Acetate extract), $\mathrm{K}^{+}, \mathrm{Ca}^{++}$and $\mathrm{Mg}^{++}$(Ammonium Nitrate extract), B ( Hot water Soluble) ]

\subsection{Proteins Analysis:}

Crude protein was determined by the Kjeldahl method as described by [8].

Leaves sample $(700 \mathrm{mg}$ ) was placed in a Kjeldahl digestion tube. $5 \mathrm{~g} \mathrm{~K} 2 \mathrm{SO} 4+0.5 \mathrm{~g} \mathrm{CuSO} 4$, and $25 \mathrm{ml}$ conc. sulphuric acid was added to the sample. The sample was digested for one hour. $20 \mathrm{ml}$ deionized water was added to the sample after allowing it to cool. After adding $25 \mathrm{ml} \mathrm{NaOH} \mathrm{(40 \% ),} \mathrm{the} \mathrm{sample} \mathrm{was} \mathrm{then} \mathrm{distilled} \mathrm{and}$ the ammonia liberated was collected in boric acid and titrated with $0.1 \mathrm{~N}$ hydrochloric acid. A blank was prepared and treated in the same manner except that the tube was free of sample.

Protein percentage was calculated according to the formula:

Crude protein $(\%)=($ sample titre - blank titre $) \times 14 \times 6.25 \times 100 /$ sample

Weight (Eq. 4). Where, 14 is molecular weight of nitrogen and 6.25 is the nitrogen factor.

\subsection{Statistical Analysis:}

The difference in minerals elements and proteins concentration during dry and wet season were calculated, SPSS 16.0 for Windows statistical package. Were used and the LSD was the statistical method used for determining the significance of difference at $\mathrm{P}=0.05$.

\section{Result and discussion:}

The Arabian Desert is classified as hyper arid with extremely hot summers and mild winters. Eastern Saudi Arabia has a subtropical desert climate, arid basically because of its geographical situation in global patterns of atmospheric circulation. Low rainfall and high temperatures certainly class the area as a desert by virtually any of the many definitions of the term, as well as the clima diagram. Climatic aridity is assessed by the scantiness and irregularity of rainfall associated with elevated air temperatures [9], the adaption of plants in Saudi Arabia desert indicate how change in gene expression lead to changes in metabolism to survive under hard conditions.

Plants samples were collected from three different sites of the Eastern region habitats. Site I is the habitat of coastal sand were coastal erosion has exposed low terraces covered additionally by coquinas and individual shells. Much of the carbonate sand found around the coasts of the Arabian Gulf was formed originally on the floor of the gulf; site II was the habitat of littoral salt marshes or salt flats (littoral sibakh) near the coast; site III was the habitat of Aeolian sands which cover the area inland. Most of the Aeolian sand is derived by deflation of young fluvial, lacustrine and coastal sands. These in turn are the products of weathering and erosion of older rocks including sandstones that originated by erosion of the basement [10].

The first time, samples were collected in the month of Aug in one day. The temperature recorded that day was [ high 41 , low $26^{\circ} \mathrm{C}$, humidity $71 \%$ ], and second time, same samples were collected from the same locations but during winter (wet) season in the month of Feb in one day and the temperature recoded that day was [ high 26 , low $13{ }^{\circ} \mathrm{C}$, humidity $42 \%$ ].

Table (1): shows the collected plants and distance from the sea; the plants were identified following [11]

1. Zygophyllum album, ( Family: Zygophyllaceae), was collected from site I ; perennial desert plants in the form of bush lets, rarely annuals, with fleshy branch lets and leaves. leaves compound bifoliate grey; leaflets cylindrical, obovate, about $7 \mathrm{~mm}$. Long, shorter than the fleshy terete petiole. Flowers small, white, peduncle shorter than flower and capsule. Capsule pear-10 mm. Long with a retuse apex. Cushion sand-accumulating plant of both desert and salt marsfg a height of $1 \mathrm{~m}$, or more.

2. Halopeplis perfoliata, ( family: Chenopodiaceae) was collected from site II; Bge ex schweinf. Arobust perennial frutescent halophytic plant of saline seashore habitats. The plant is as tout juicy succulent undershrub. Leaf rudiments nearly spherical and enclosing the stem, thus looking like peculiar swollen joints.

3. Cyperus conglomeratus, ( Family: Cyperaceae), Two samples were collected, (A) from site I and (B) from site III; Densely-tufted, pale-green, glabrous perennial plant, with usually woolly fibrous roots. Stem compressed, 10-30 cm long, round-trigonous, obtuse-angled towards the top, leafy at the base. Leaves terete, grooved, pungent, with very obscure midrib and much in rolled margins when dry. Inflorescence either $2-4$ short (up to $2 \mathrm{~cm}$ long) umbel rays or forming a head about $35 \mathrm{~mm}$ across. Bracts $2-4$, sometimes a continuation of the stem. Spikeletes pale, 6 or more together 8-16-flowered each; nut trigonous, style bifid. Maritime sands and deserts 
4. Zygophyllum decumbens, ( Family: Zygophyllaceae), was collected from site III; Low shrubs with prostrate branches. Leaves compound bifoliate, with fleshy, flattened, broadly obovate leaflets. Flowers small, white, capsule pear-shaped, small, up to $10 \mathrm{~mm}$. Long, deeply 5-parted.

\subsection{Minerals Elements analysis:}

Table (2): shows the $\mathrm{pH}$ value, and the electrical conductivity of tested soils, it indicates that soils salinity differed from one location to another, and that due to the wide topographic changes in Eastern region incur formation of various habitat types and under extremely arid climatic conditions. Variations in physiographic and edaphic factors determine soil moisture availability which is a paramount factor determining plant life [9].

Tables (3\&4) and fig (1\&2): show the result of the minerals elements samples $\left(\mathrm{Cl}^{-}, \mathrm{Na}^{+}, \mathrm{K}^{+}, \mathrm{Ca}^{++}, \mathrm{Mg}^{++}, \mathrm{B}^{+++}\right)$ that were analyzed and determined for their concentrations in soil, and as a result effects the concentration of different soil salts.

During dry season the result shows that concentrations of the tested minerals increased in all soil samples except for the soil sample that collected from site I, were the habitat of coastal sand and Site II, were the habitat of littoral salt marshes (littoral sibakh) near the coast, show a different result, and that is most of the minerals decreased. The increase of the minerals concentrations can be explained as [12] reported that increase in temperature lead to physical changing like evaporation which resulted in increasing the soil water deficit and this lead to increasing minerals concentration and to the inhibition of water absorbance by plant roots because of water potential, similar result reported by $[(13 ; 14]$. The decreased concentration on the littoral minerals marshes (littoral sibakh) and coastal sand indicate that the change in temperature and humidity had less effect because of their location near the sea, which cause high humidity and increase the solubility of minerals, and also plants grow in these tow habitats had especial anatomical and adaptive characters that helps in absorb minerals even with water potential [15].

The concentration of minerals from high to low concentrations recorded during the dry season were as follow: calcium $>$ chloride $>$ sodium $>$ magnesium $>$ potassium $>$ boron.

The concentrations of minerals decreased during the wet season in all soil samples .This decrease in minerals concentrations may be due to the low temperature which lead to decrease water evaporation of the soils, and the air relative humidity lead to decreased minerals solubility and their concentrations [16], beside with the few rain fall, the water leaked deep in soil with the soluble minerals. The results show that the soil collected from site II recorded high concentration of minerals which induce high level of salinities; and this because of sandy clay loam that characterized these habitats [17]; the concentration recorded from high to low as follow: chloride $>$ calcium $>$ sodium $>$ magnesium $>$ potassium and the lowest concentration were boron.

For littoral salt marshes (littoral sibakh) the high concentrations of the chloride and sodium due to the natural need of these kind of growing halophytes plants in their environmental [18], also [19] reported that halophytes need to increase the absorption of calcium and magnesium to balance the harmful effect of chloride and sodium ions. The rest of soil samples, calcium recorded the highest concentration during the wet season compared with other minerals where boron was the lowest.

\subsection{Proteins analysis:}

In chromosomes, each allele codes for the production of amino acids that string together to form proteins. Thus, the difference in the nucleotide sequence of alleles results in the production of slightly different strings of amino acids or variant forms of proteins. These proteins code for the development of morphological, anatomical and physiological characteristics of the organism and are also responsible for determining aspect of the behavior of the organism [20], also [21] reported that desert plants have adaptive characters that qualify it to grow normally with ecological stress.

Table (5) and fig (3) show the result of proteins concentrations.

The nitrogen concentration increase during the dry season, it was significant at $\mathrm{p}>0.05$, and that result from decrease in concentration of un soluble proteins and increase in soluble proteins, this may be due to the high concentration of salts in soil around the plants roots, this with the effects of high temperatures and high humidity induce salt and water stress to plants, which lead to a decrease in proteins content [22]. [23] reported that under high concentration of salts $(\mathrm{Na} \mathrm{Cl})$ and the activities of both acid and alkaline protease increased, lead to an increase in free amino acids, also [12] reported that water stress disrupted the nitrogen metabolism leading to proteins solubility and accumulation of amino acids. [24] found that amino acids concentration decrease because of decreasing nitrate reeducates enzymes responsible for transforming $\mathrm{No}_{3}^{-}$to $\mathrm{NO}_{2}^{-}$in tobacco plants under drought stress. These changes in proteins content may be due to adaptation of the plants with the change of salts concentration. 
The concentration of protein varied between tested sample as follow Cyperuse conglomeratus(B)> Halopeplis perfoliata > Zygophyllum album >Cyperaceae conglomeratus (A) > Zygophyllum decumbens, were Cyperaceae conglomeratus (B) recorded the highest sample of soluble proteins content and Zygophyllum decumbens recorded the lowest sample of soluble proteins content. This differences in proteins content may be due to adaptive characters of plants [25].

The result shows decrease in nitrogen concentration during wet season, it was significant at $p>0.05$, and that result from the increase in un soluble proteins. The decrease in soluble proteins concentration, may be due to the decrease of temperature, evaporation; this decrease in soluble proteins may be due to proteins building activity.

The contents of protein also varied between tested sample as follow Cyperaceae conglomeratus $(\mathrm{B})>$ Cyperaceae conglomeratus (A) > Zygophyllum album > Zygophyllum decumbens > Halopeplis perfoliata, were Cyperaceae conglomeratus(B) recorded the highest sample of unsoluble proteins content and Halopeplis perfoliata recorded the lowest sample of unsoluble proteins content.

\section{Conclusion:}

The adaptive characters of plants help them tolerate changes in temperatures during dry and wet seasons, which affects the concentration of soil minerals around the roots of the plants; The minerals concentrations increased in the dry season because of high temperature and high evaporation that induce high level of air humidity, and lead to a decrease in protein contents as a result of salt and water stress, while in the wet season where temperature decreased with few rainfall percentage, decreased the salinity of the soil and lead to high activity of proteins building, except the littoral salt marshes which show different results during dry and wet seasons; minerals concentration were high compared to other examined habitats, and this is due to the increase of soil water deficit because of the characteristics of the soil of these habitat.

\section{References}

[1] D.J. Bowles, Defens-related proteins in higher plants., Annu. Rev. Biochem., 59, 1990:873-907.

[2] K. Kanlaya, D. Sakda, W. Chaisri, B. Sumontip, K. Manit, and T. Piyada, Protein profiles in response to salt stress in leaf sheaths of rice seedlings. Science Asia 31, 2005.403-808.

[3] G. A. Swire- Clark and W. R. Jr. Marcotte, The wheat LEA encoding oxygen evolving enhancer protein 1 increased by salt treatment in the mangrove Bruguiera gymnorhiza. Plant cell Physiol. 41, 1999. 1279-1285.

[4] X. Y Xu, M. Abo, A. Okubo, and S. Yamazaki, Salt- stress- responsive membrane proteins in Rhodobacter sphaeroides f.sp. denitrificans IL106. J. Biosci. Bioeng. 91, 2001.228-230

[5] P. A. Yash and T. I. Keith, Effects of higher day and night temperatures on growth and yields of some crop plants. Natural Resources Management and Environment Department. 1996: 1- 15.

[6] F. J. Welcher, Standard Methods of Chemical analysis. ( $6^{\text {th }}$ Edition, Krieger, F. Publishing Co., Florida, U.S.A. 1975)

[7] Agriculture Handbook No.60 (published by USDA, Washington. D. C., U. S. A. 1969)

[8] A. O. A. C (). Official Methods of chemical Analysis, (15 ${ }^{\text {th }}$ Edition, Florida, U. S. A. 1990)

[9] T. M. Oberlander, Global deserts: a geomorphic Comparison. In: Geomorphology of desert environments. 1994, 13-35.Chapman a Hall. London.

[10] H. White, and J. Leonard, Phytogeraphical links between Africa and South west FI. Veg. Mundi.9, 1991.229-246.

[11] A. M. Migahid, Flora of Saudi Arabia. Vol1. (Second edition. Riyadh UN. Publication. 1978)

[12] P. J. Kramer, Water Relations of plants. Academic Press. New York, London, Paris, Sam Diego, San Francisco, Soabulo, Tokyo, Toronto. 1983, Pp.488.

[13] A. M. Casas, R. A. Bressan, and P. M. Hasegawa, Cell growth and water relations of the halophyte, Atriple. 1991

[14] A. A. Very, M. F. Robinson, A. T. Mansfield, and D. Sanders, Guard cell action channels are involved in Na+ induced stomatal closure in a halophyte. Plants Journal.14(5), 1998: 509- 521.

[15] Y. Uchiyama, Salt tolerance of Atriplex numularia. Tech Bull. Trop. Agr. Research Center, Japan, 22. 1987,1-69.

[16] Uner, The most optamian Marshlands: Demise of an Ecosystem. United Nation Environment Programme, Division of Early Warning. 2001.

[17] J. P. Mandaville, Flora of Eastern Saudi Arabia. Kegen Paul international. London and New York. 1990

[18] R. G. Wyn Jones, Salt tolerance. In: Physiological processes limiting plant productivity . Johnson, C. B.(Ed.) Butterworth Press, London. 1981, 271-292.

[19] W. A. Girgis, A. M. Ahmed, and A. A. Shalaby, Studies on halophytes to their environment. Fac. Agric Research Bull: 1003. 1979, $1-21$.

[20] M. T. Bhat, S. Choudhary, M. Ansari, R. Alka and Aslam, Genotoxicity and molecular screening of proteins in root tip cells of Trigonella foenum- graecum ( Fenugreek var- Azad) under cadmium stress condition. International journal of plant physiology and Biochemistry. 4(3), 2012, 41-46.

[21] D. M. Moor, Green planet. The stony of plant life on Earth. (Cambridge UNIV. Press. Cambridge London. New York Rochelle Melbourne Sydney. 1982)

[22] A. A. Abd El-Rahman, N.H. Ezzat, and A.H. Hassan, Variations in the composition of plant mineral in different ecological group. Flora. (Abt. BD.),1975,164. 73-84.

[23] A. K. Parida, A. B. Das, B. Mittra, and P. Mohanty, Salt-stress Induced Alterations in Proteins Profile and Protease Activity in the Mangrove Bruguiera parviflora Z. Naturfors ch. 59c. 2004,408-414.

[24] S. Ferrario-Mery, M. Valadier, and C. Foyer, Over expreeion of nitrate reductas in tobacco delays drought- induced decreases in nitrate reductase activity and mRNA . Plant Physiol.117. 1998, 293-302.

[25] P.J. Kramer, Drought stress, and the origin of adaptation In: adaption to plants to water and high temperature stress. Turner, N. C. \& Kramer (Eds.), P. J. John Wiley \& Sons. 1980, 1 - 7 
Effects of Dry and Wet Seasons on Some Soil Minerals and Proteins in some Plants Table (1 ) : plants sample collected from the flora of Eastern region of Saudi Arabia.

\begin{tabular}{|c|cccc}
\hline & plants & Family & sits & $\begin{array}{c}\text { Distance } \\
\text { from Gulf } \\
\text { sea }(\mathrm{Km})\end{array}$ \\
\hline 1 & Zygophyllum album & Zygophylaceae & sit I & location \\
\hline 2 & Halopeplis perfoliata & Chenopodiaceae & sit II & costal sand \\
\hline 3 & Cyperus conglomeratus $(\mathrm{A})$ & Cyperaceae & sit I & salt marshes \\
\hline 4 & Zygophyllum decumbens & Zygophylaceae & sit III & costal sand \\
\hline 5 & Cyperus conglomeratus $(\mathrm{B})$ & Cyperaceae & sit III & Aeolian sands \\
\hline
\end{tabular}

Table (2 ): PH value, Electrical conductivity and salinity of collected soil around the roots of collected plants

\begin{tabular}{|lcccccc}
\hline \multicolumn{1}{c}{ plants } & \multicolumn{2}{c}{ PH value } & \multicolumn{2}{c}{$\begin{array}{c}\text { Electrical } \\
\text { conductivity }\end{array}$} & Salinity of soil \\
\hline \multicolumn{1}{c}{ season } & dry & wet & dry & wet & dry & wet \\
\hline Zygophyllum album & 6.7 & 7.5 & 2430 & 2560 & Low salinity & Medium salinity \\
\hline Halopeplis perfoliata & 7.0 & 7.8 & 18000 & 31400 & High salinity & High salinity \\
\hline Cyperus conglomeratus (A) & 7.3 & 7.8 & 2300 & 2010 & Medium salinity & Low salinity \\
\hline Zygophyllum decumbens & 7.3 & 7.9 & 551 & 170 & Low salinity & Low salinity \\
\hline Cyperus conglomeratus $(\mathrm{B})$ & 7.0 & 7.5 & 495 & 586 & Low salinity & Low salinity \\
\hline
\end{tabular}

Table (3 ): concentration of soil minerals, collected from different sits during dry season.

\begin{tabular}{|c|c|c|c|c|c|}
\hline $\begin{array}{c}\text { examined } \\
\text { salts }\end{array}$ & $\begin{array}{c}\text { Zygophyllum } \\
\text { album }\end{array}$ & $\begin{array}{c}\text { Halopeplis } \\
\text { perfoliata }\end{array}$ & $\begin{array}{c}\text { Cyperus } \\
\text { conglomeratus } \\
(\mathrm{A})\end{array}$ & $\begin{array}{c}\text { Zygophyllum } \\
\text { decumbens }\end{array}$ & $\begin{array}{c}\text { Cyperus } \\
\text { conglomeratus (B) }\end{array}$ \\
\hline \multicolumn{7}{c}{ concentration/ppm } \\
\hline $\mathrm{CL}^{-}$ & 148 & 4445 & 361 & 73 & 65 \\
\hline $\mathrm{Na}^{+}$ & 117 & 1940 & 208 & 105 & 132 \\
\hline $\mathrm{K}^{+}$ & 57 & 229 & 54 & 102 & 821 \\
\hline $\mathrm{Ca}^{++}$ & 2364 & 5170 & 1403 & 681 & 123 \\
\hline $\mathrm{Mg}^{++}$ & 160 & 530 & 129 & 137 & 0.26 \\
\hline $\mathrm{B}^{++}$ & 0,59 & 2.35 & 0.71 & 0.28 \\
\hline
\end{tabular}

Table (4) : concentration of soil minerals, collected from different sits during wet season.

\begin{tabular}{|c|c|c|c|c|c|}
\hline examined salts & $\begin{array}{c}\text { Zygophyllum } \\
\text { album }\end{array}$ & $\begin{array}{c}\text { Halopeplis } \\
\text { perfoliata }\end{array}$ & $\begin{array}{c}\text { Cyperus } \\
\text { conglomeratus } \\
\text { (A) }\end{array}$ & $\begin{array}{c}\text { Zygophyllum } \\
\text { decumbens }\end{array}$ & $\begin{array}{c}\text { Cyperus } \\
\text { conglomeratus (B) }\end{array}$ \\
\hline \multicolumn{7}{|c|}{ concentration/ppm } \\
\hline $\mathrm{CL}^{-}$ & 155 & 9466 & 70 & 13 & 37 \\
\hline $\mathrm{Na}^{+}$ & 61 & 6300 & 50 & 19 & 50 \\
\hline $\mathrm{K}^{+}$ & 60 & 336 & 51 & 45 & 1167 \\
\hline $\mathrm{Ca}^{++}$ & 3376 & 8770 & 2302 & 1072 & 10 \\
\hline $\mathrm{Mg}^{++}$ & 116 & 1772 & 45 & 14 & 0.1 \\
\hline $\mathrm{B}^{+++}$ & 0.3 & 3.7 & 0.2 & 0.1 & \\
\hline
\end{tabular}


Effects of Dry and Wet Seasons on Some Soil Minerals and Proteins in some Plants

Table ( 5 ) : Proteins concentration in leaves of collected samples during dry and wet seasons.

\begin{tabular}{|c|c|c|c|c|c|}
\hline $\begin{array}{l}\text { Seasons \& } \\
\text { sites }\end{array}$ & $\begin{array}{c}\text { Zygophyllum } \\
\text { album }\end{array}$ & $\begin{array}{c}\text { Halopeplis } \\
\text { perfoliata }\end{array}$ & $\begin{array}{c}\text { Cyperaus } \\
\text { conglomeratus (A) }\end{array}$ & $\begin{array}{c}\text { Zygophyllum } \\
\text { decumbens }\end{array}$ & $\begin{array}{c}\text { Cyperus } \\
\text { conglomeratus (B) }\end{array}$ \\
\hline & Site I & Site II & Site I & Site III & Site III \\
\hline wet & 4.81 & 3.25 & 5.63 & 4.19 & 10.15 \\
\hline dry & 20.68 & 25 & 14.06 & 14.06 & 35.18 \\
\hline
\end{tabular}

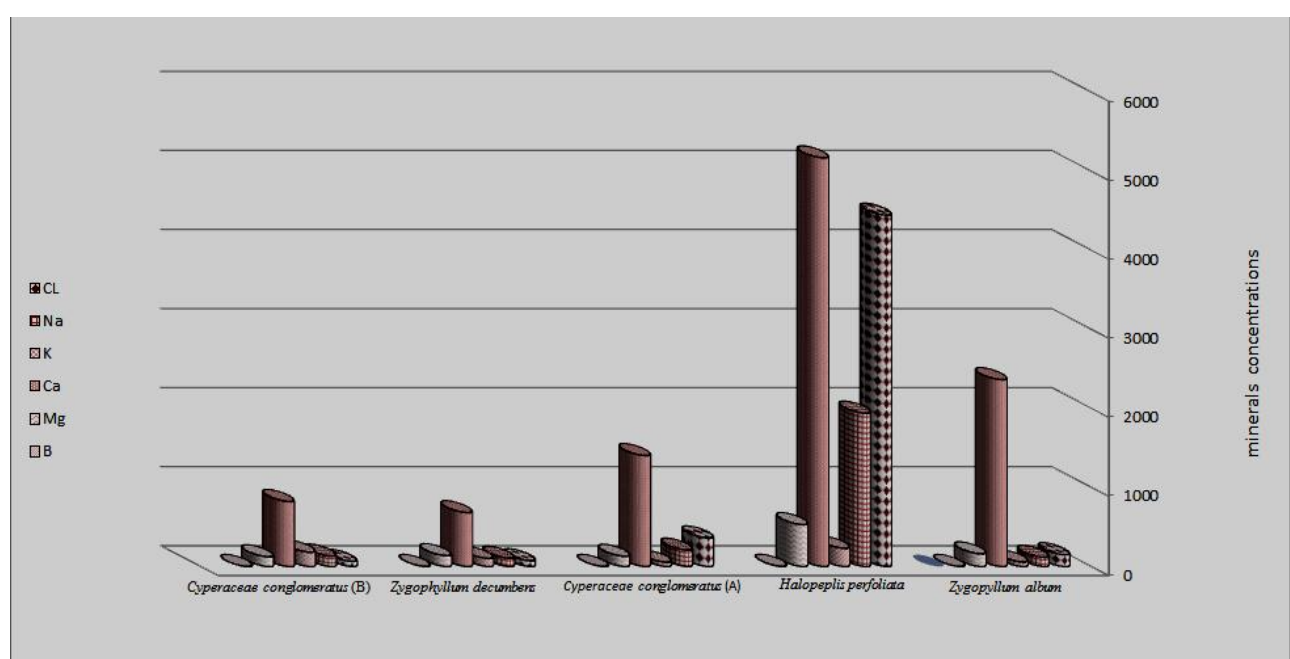

figur (1): concentration of minerals in soil collected from different locations during summer ( dry) seasone

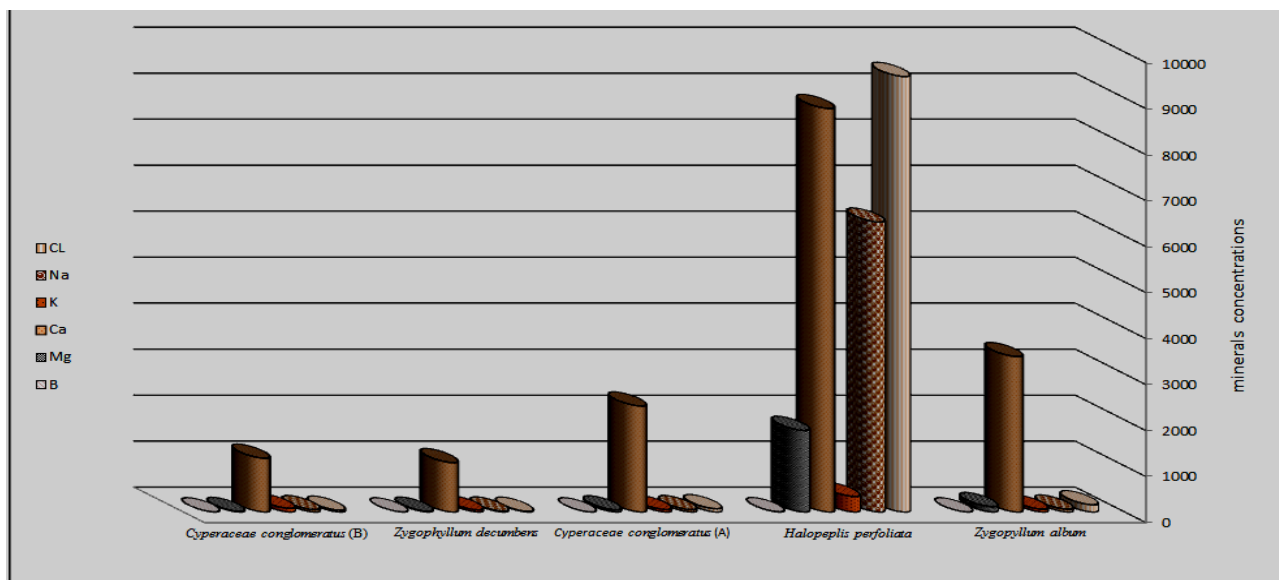

Figur (2): concentration of minerals in soil collected from different locations during winter ( wet) season

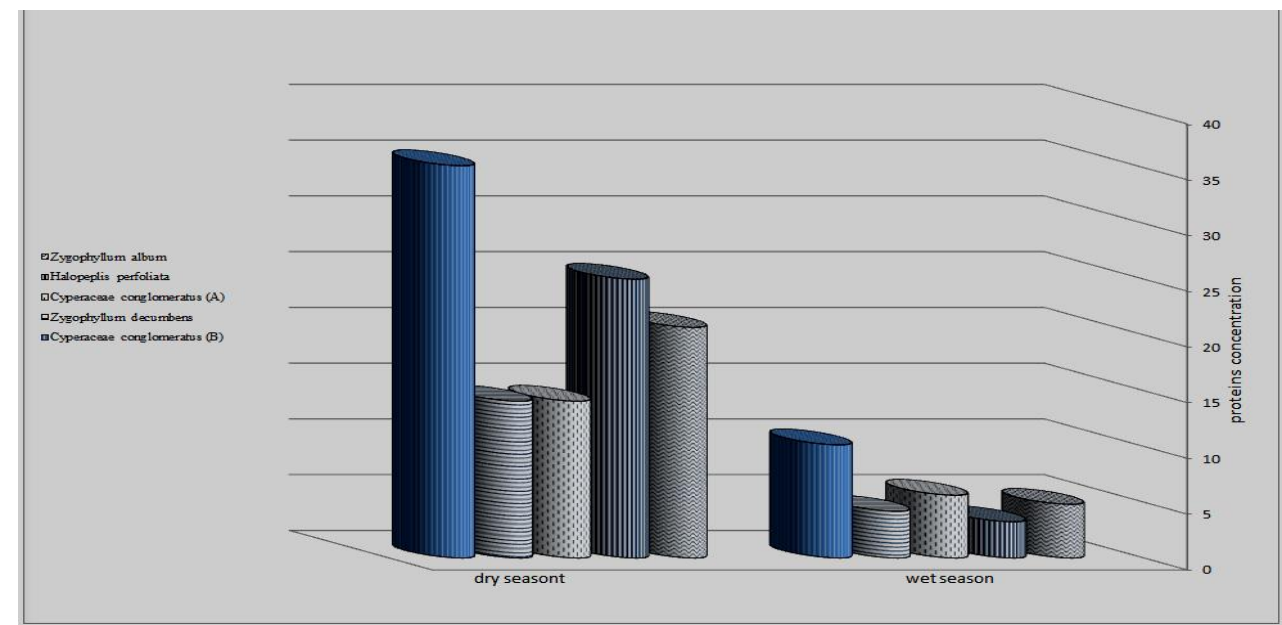

Figure (3): Protein concentration in leaves from different plants of Saudi Arabia flora 